\title{
One-Electron Oxidation of a Hydrogen-Bonded Phenol Occurs by Concerted Proton-Coupled Electron Transfer
}

\author{
Ian J. Rhile and James M. Mayer* \\ University of Washington, Department of Chemistry, \\ Box 351700, Seattle, WA 98195, mayer@chem.washington.edu
}

\section{Supporting Information}

\section{General Experimental}

Unless otherwise noted, all reagents were purchased from the Aldrich Chemical Company, all solvents from Fischer, and deuterated solvents from Cambridge. 2-Bromo-4,6-di$t$-butylphenol was purchased from Lancaster, Inc. Butyllithium in hexanes was purchased from Acros. Ammonia was purchased from Matheson. Ether was purified by vacuum transfer from sodium benzophenone ketal. $\mathrm{NOPF}_{6}$ was purchased from Alfa Aesar.

${ }^{1} \mathrm{H}$ NMR and ${ }^{13} \mathrm{C}$ NMR were recorded on a Bruker AF301, Bruker AV301, or Bruker DRX499 spectrometers operating at 301 or $499 \mathrm{MHz}$ at ambient temperatures and chemical shifts are reported relative to TMS in ppm. UV/Vis spectra were obtained on a Hewlett Packard 8453 diode array spectrophotometer are reported as $\lambda_{\max }$ in $\mathrm{nm}\left(\varepsilon, \mathrm{M}^{-1} \mathrm{~cm}^{-1}\right)$, except for the long pathlength spectrum which was obtained on a CARY-500 instrument. All fits were done in KaleidaGraph except where Microsoft Excel $^{1}$ is specified.

\section{Syntheses}

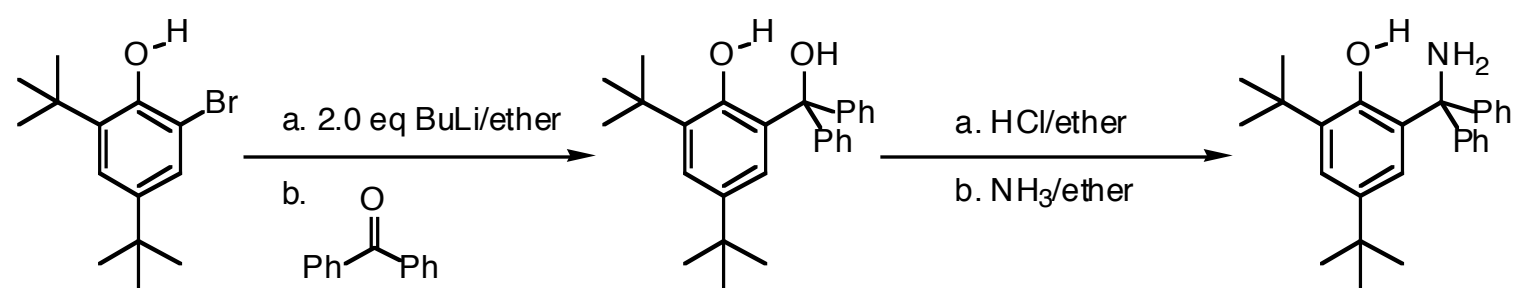

\section{2,4-Di-tert-butyl-6-(hydroxydiphenylmethyl)phenol ${ }^{2}$ (HOAr-OH)}

To a solution of 2-bromo-4,6-di-t-butylphenol $(0.771 \mathrm{~g}, 2.70 \mathrm{mmol}, 1$ equiv) in $50 \mathrm{~mL}$ ether at $-78^{\circ} \mathrm{C}$ was added a solution of $1.6 \mathrm{M}$ butyllithium in hexanes $(3.38 \mathrm{~mL}, 5.41 \mathrm{mmol}, 2.0$ equiv). The solution was warmed to $0{ }^{\circ} \mathrm{C}$ and stirred for $30 \mathrm{~min}$. After re-cooling to $-78{ }^{\circ} \mathrm{C}$, a solution of benzophenone $(0.517 \mathrm{~g}, 2.84 \mathrm{mmol}, 1.05$ equiv) in ether $(6 \mathrm{~mL})$ was added. The solution was warmed to room temperature and after $\sim 2 \mathrm{~h}$, saturated aqueous ammonium chloride was added. Additional ether was added, and the organic layer separated. The ether was washed with water and saturated aqueous sodium chloride; dried over magnesium sulfate; and filtered. After concentration by rotary evaporation, the solid was recrystallized from hexanes. Often there was residual 2,4-di-tert-butylphenol in the solid by ${ }^{1} \mathrm{H}$ NMR, which could be removed by multiple recrystallizations. The yield was $0.998 \mathrm{~g}(86 \%) .{ }^{1} \mathrm{H} \mathrm{NMR}\left(\mathrm{CDCl}_{3}\right.$, Figure S1) $\delta 1.11$ $(\mathrm{s}, 9 \mathrm{H}), 1.40(\mathrm{~s}, 9 \mathrm{H}), 3.47(\mathrm{~s}, 1 \mathrm{H}), 6.33(\mathrm{~d}, 1 \mathrm{H}, J=2.6 \mathrm{~Hz}), 7.48-7.17(\mathrm{~m}, 11 \mathrm{H}) \mathrm{ppm} .{ }^{13} \mathrm{C}\left\{{ }^{1} \mathrm{H}\right\}$

(1) Billo, E. J. Excel ${ }^{\circledR}$ for Chemists, 2nd ed. Wiley, New York: 2001.

(2) Talley J. J.; Evans, I. A. J. Org. Chem. 1984, 49, 5267-5269. 
NMR $\left(\mathrm{CD}_{3} \mathrm{CN}\right) \delta 154.18$ (C-1), 146.49 (C-1'), 140.51 (C-4), 137.17 (C-2), 130.90 (C-6), 128.79, 128.68 (C-2', C-3'), 128.54 (C-4'), 125.91 (C-3), 124.29 (C-5), $85.55(\mathrm{C}-\mathrm{OH}), 35.68,34.67\left({ }^{t} \mathrm{Bu}\right.$

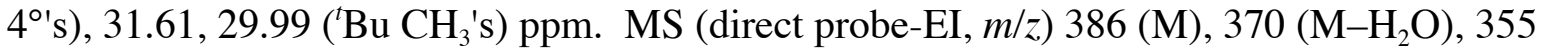
$\left(\mathrm{M}-\mathrm{H}_{2} \mathrm{O}-\mathrm{CH}_{3}\right), 293\left(\mathrm{M}-\mathrm{H}_{2} \mathrm{O}-\mathrm{Ph}\right)$.

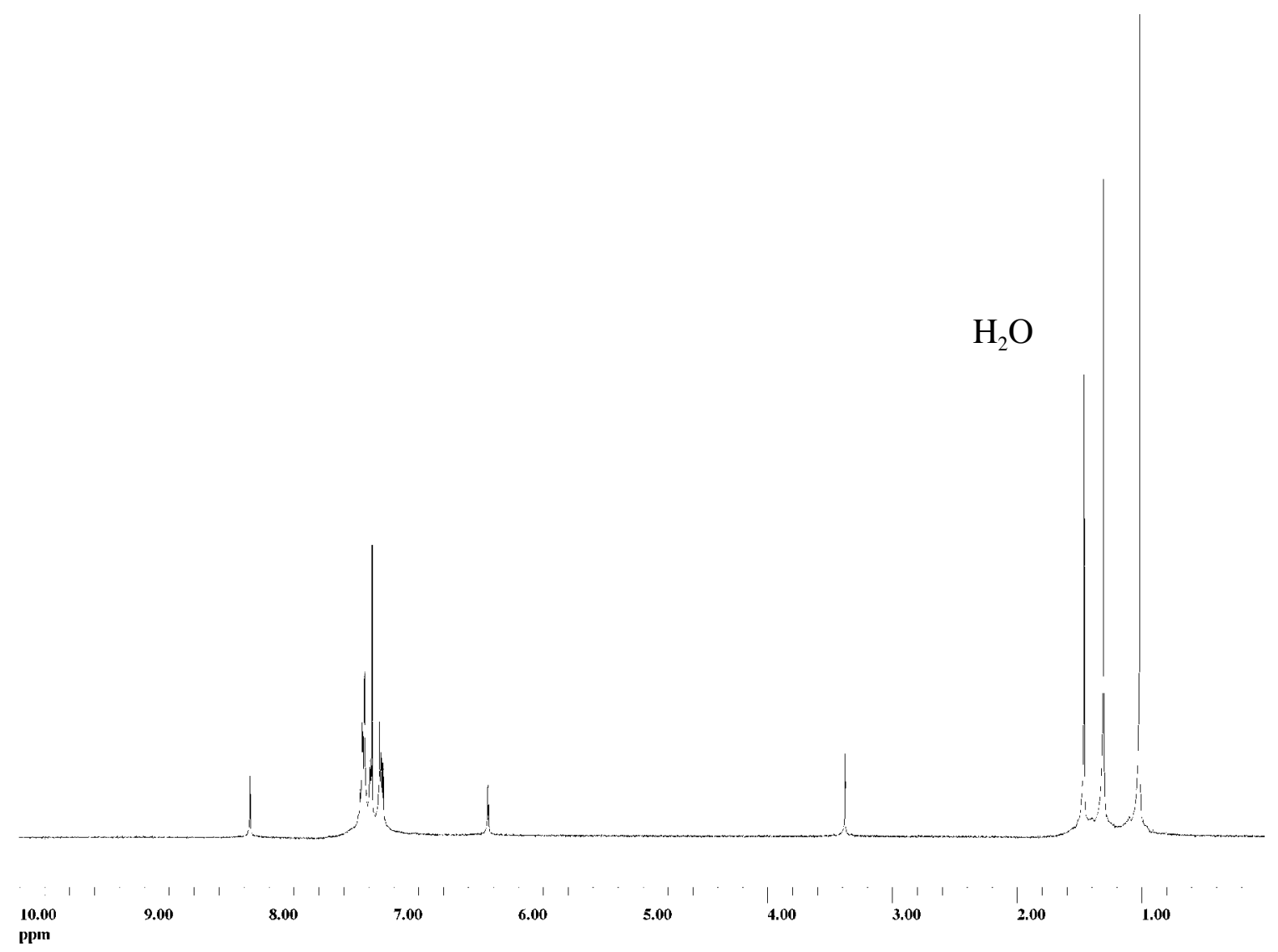

Figure S1. ${ }^{1} \mathrm{H}$ NMR of HOAr-OH.

\section{2-(Aminodiphenylmethyl)-4,6-di-tert-butylphenol ${ }^{3}$ (HOAr-NH ${ }_{2}$ )}

Hydrogen chloride gas was bubbled through a ethereal solution $(50 \mathrm{~mL})$ of HOAr-OH $(5.06 \mathrm{~g}, 13.0 \mathrm{mmol})$ in ether for $\sim 30 \mathrm{~min}$, after which the solution was green. The ether was removed by vacuum transfer, and fresh, dry ether was vacuum transferred to the solution. (The chloride was not isolated as it is unstable. ${ }^{3}$ ) Ammonia was bubbled through the solution for $\sim 10$ minutes, during which time the solution became blood red. After additional stirring, the solution gradually became colorless. The ether was removed by vacuum transfer. Column chromatography (gradient $5 / 2$ to $2 / 1 \mathrm{v} / \mathrm{v}$ hexanes/chloroform) followed by recrystallization yielded the product. The yield was $3.76 \mathrm{~g}(67 \%)$ based on HOAr- $\mathbf{N H}_{2} \bullet 0.5 n$-hexane (see crystal structure). ${ }^{1} \mathrm{H}$ NMR $\left(\mathrm{CD}_{3} \mathrm{CN}\right.$, Figure S2) $\delta 1.09(\mathrm{~s}, 9 \mathrm{H}), 1.37(\mathrm{~s}, 9 \mathrm{H}), 6.42(\mathrm{~d}, 1 \mathrm{H}, J=2.0 \mathrm{~Hz})$, 7.38-7.09 (m, 11H) ppm. ${ }^{13} \mathrm{C}\left\{{ }^{1} \mathrm{H}\right\}$ NMR $\left(\mathrm{CD}_{3} \mathrm{CN}\right) \delta 156.03(\mathrm{C}-1), 147.67(\mathrm{C}-1$ '), $139.63(\mathrm{C}-4)$, 136.98 (C-6), 130.44 (C-2), 128.83, 128.66 (C-2', C-3'), 127.90 (C-4'), 126.26 (C-3), 123.91 (C-

(3) (a) Gomberg, N.; Nishida, D. J. Chem. Soc. 1922, 190-207. (b) Mandell, L.; Piper, J. V.; Pesterfield, C. E. J. Org. Chem. 1963, 28, 574-575. 
5), $68.57\left(\underline{\mathrm{C}}-\mathrm{NH}_{2}\right), 35.65,34.66\left({ }^{t} \mathrm{Bu} 4{ }^{\circ} \mathrm{s}\right), 31.67,29.9799\left({ }^{t} \mathrm{Bu} \mathrm{CH}_{3}{ }^{\prime} \mathrm{s}\right)$ ppm. MS (direct probe$\mathrm{EI}, \mathrm{m} / z) 387(\mathrm{M}), 370\left(\mathrm{M}-\mathrm{NH}_{3}\right), 355\left(\mathrm{M}-\mathrm{NH}_{3}-\mathrm{CH}_{3}\right), 293\left(\mathrm{M}-\mathrm{NH}_{3}-\mathrm{Ph}\right)$.

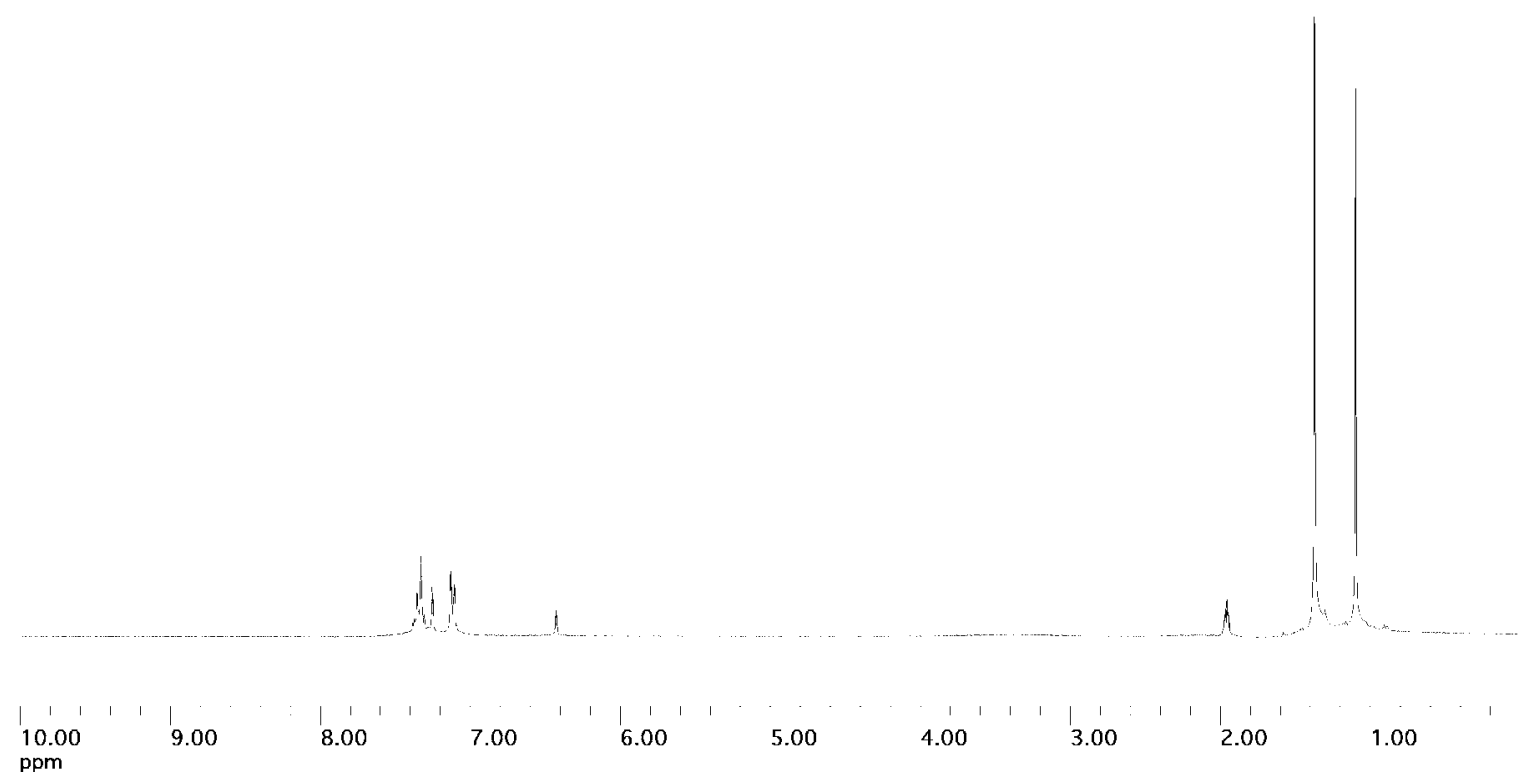

Figure S2. ${ }^{1} \mathrm{H}$ NMR of HOAr- $\mathrm{NH}_{2}$.

\section{Oxidants}

The iron bipyridyl complexes were synthesized according to literature procedures ${ }^{4}$ and were used as $\mathrm{PF}_{6}^{-}$salts. (4-Bromophenyl)-di(4-anisyl)amine, di(4-bromophenyl)(4-anisyl)amine and tri-4- $p$-anisylamine were synthesized by literature procedures. ${ }^{5}$ The triarylamines were oxidized with $\mathrm{NOPF}_{6}{ }^{6}$ or $\mathrm{SbCl}_{5}{ }^{6 \mathrm{~b}, 7}$ to yield the aminium salts. $\mathrm{SbCl}_{6}{ }^{-}$salts were only used for kinetics experiments with $\mathrm{Ntol}_{3}{ }^{\circ+}$.

(4) DeSimone, R. E.; Drago, R. S. J. Am. Chem. Soc. 1970, 92, 2343-2352.

(5) Bonhôte, P.; Moser, J.-E.; Humphry-Baker, R.; Vlachopoulos, N.; Zakeeruddin, S. M.; Walder, L.; Grätzel, M. J. Am. Chem. Soc. 1999, 121, 1324-1336.

(6) (a) Bandlish, B. K.; Shine, H. J. Org. Chem. 1977, 42, 561. (b) Eberson, L.; Larsson, B. Acta Chem. Scand., Ser. B 1986, 40, 210. (c) Eberson, L.; Larsson, B. Acta Chem. Scand., Ser. B 1987, 41, 367.

(7) (a) Dapperheld, S.; Steckhan, E.; Grosse Brinkhaus, K.-H.; Esch, T. Chem. Ber. 1991, 124, 2557. (b) Schmidt, W.; Steckhan, E. Chem. Ber. 1980, 113, 577. (c) Bell, F. A.; Ledwith, A.; Sherrington, D. C. J. Chem. Soc. C 1969, 2719. 


\section{X-ray Crystal structure of HOAr- $\mathrm{NH}_{2}$.}

Crystals were grown from hot hexanes and a colorless crystal $(0.42 \times 0.28 \times 0.28 \mathrm{~mm})$ mounted on a glass capillary with. Data were collected at $-143{ }^{\circ} \mathrm{C}$ with one set of $\varphi$ scans; the scanlength was $183.0^{\circ}$, starting at $\theta=3.703, \varphi=1.5, \Omega=160$, and $\kappa=0.000$. Crystal-to-detector distance was $30 \mathrm{~mm}$ and exposure time was $2 \mathrm{~s}$ per degree for all. The scan width was $2.0^{\circ}$. Data collection was $91.0 \%$ complete to $24.71^{\circ}$ in $\theta$. Collection and refinement data are given in Table S1. The data was integrated and scaled using hkl-2000. This program applies a multiplicative correction factor (S) to the observed intensities $(I)$ and has the following form: $\mathrm{S}=$ $\left(\mathrm{e}^{-2 \mathrm{~B}\left(\sin ^{2} \theta\right) / \lambda^{2}}\right) / \mathrm{scale}$. $\mathrm{S}$ is calculated from the scale and $\mathrm{B}$ factor, which is determined for each frame and is then applied to $I$ to give the corrected intensity $\left(I_{\text {corr }}\right)$. Solution by direct methods (SIR97) produced a complete heavy atom phasing model consistent with the proposed structure. All hydrogen atoms were placed using a riding model except for the hydroxyl $(\mathrm{O}-\underline{\mathrm{H}})$ and amino $(\mathrm{N}-\underline{\mathrm{H}})$ hydrogens, which were located and refined isotropically by full-matrix least squares. All non-hydrogen atoms were refined anisotropically by full-matrix least-squares. One molecule of $n$-hexane co-crystallized with four molecules of the molecule, forming the asymmetric unit. Data for the hydrogen bond in each of the two distinct molecules is listed in Table S2.

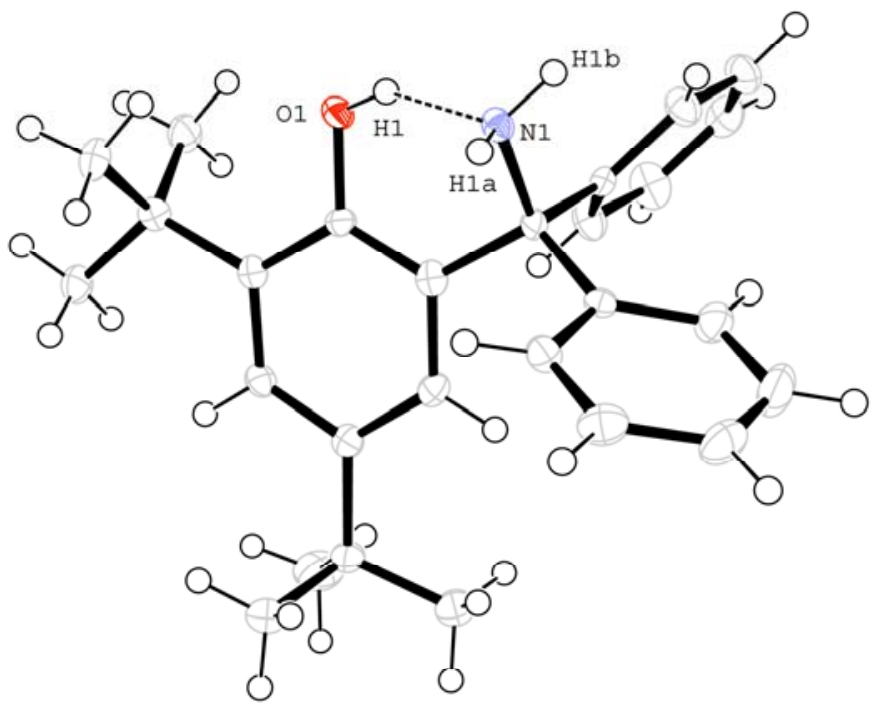

Figure S3. ORTEP drawing of the X-ray crystal structure of HOAr-NH2. 
Table S1. Collection and refinement data

\begin{tabular}{|c|c|}
\hline empirical formula & $\mathrm{C}_{60} \mathrm{H}_{80} \mathrm{~N}_{2} \mathrm{O}_{2}$ \\
\hline formula weight & 861.30 \\
\hline temperature $(\mathrm{K})$ & $130(2)$ \\
\hline wavelength $(\AA)$ & 0.7073 \\
\hline crystal description/color & prism/colorless \\
\hline crystal system & triclinic \\
\hline point group & $P \overline{1}$ \\
\hline \multirow[t]{6}{*}{ unit cell dimensions $\left(\AA\right.$ or $\left.^{\circ}\right)$} & $a=11.4910(3)$ \\
\hline & $b=14.9150(7)$ \\
\hline & $c=15.1270(8)$ \\
\hline & $\alpha=75.4340(16)$ \\
\hline & $\beta=79.8130(14)$ \\
\hline & $\gamma=74.796(3)$ \\
\hline volume $\left(\AA^{2}\right)$ & $2403.22(18)$ \\
\hline density $\left(\mathrm{mg} / \mathrm{m}^{3}\right.$, calcd $)$ & 1.131 \\
\hline$\mu\left(\mathrm{mm}^{-1}\right)$ & 0.067 \\
\hline$F(000)$ & 890 \\
\hline crystal size & $(0.42 \times 0.28 \times 0.28 \mathrm{~mm})$ \\
\hline reflections for indexing & 1400 \\
\hline$\theta$ range $\left(^{\circ}\right)$ & $2.93-24.71$ \\
\hline \multirow[t]{3}{*}{ index ranges } & $-13 \leq h \leq 12$ \\
\hline & $-17 \leq k \leq 14$ \\
\hline & $-17 \leq l \leq 17$ \\
\hline collected reflections & 11329 \\
\hline unique collections & 7464 \\
\hline$R_{\text {int }}$ & 0.0624 \\
\hline completeness to $\theta$ & $24.71(91.0 \%)$ \\
\hline absorption correction & HKL-2000 \\
\hline $\max / \min$ transmission & $0.9815 / 0.9724$ \\
\hline refinement method & full-matrix least squares on $F^{2}$ \\
\hline data & 7464 \\
\hline restraints & 0 \\
\hline parameters refined & 581 \\
\hline final $R, R_{w}(\mathrm{I}>2 \sigma \mathrm{I})$ & $0.0573,0.1367$ \\
\hline goodness-of-fit & 1.003 \\
\hline largest diff. hole and peak $\left(\mathrm{e} \bullet \AA^{2}\right)$ & $0.057,-0.313$ \\
\hline
\end{tabular}

Table S2. Hydrogen-bonding data.

\begin{tabular}{lllll}
\hline & $\mathrm{d}(\mathrm{O}-\mathrm{H}), \AA$ & $\mathrm{d}\left(\mathrm{H}^{\cdots} \mathrm{N}\right), \AA$ & $\mathrm{d}(\mathrm{O} \cdots \mathrm{N}), \AA$ & angle, OHN $\left(^{\circ}\right)$ \\
\hline $\mathrm{O}(1)-\mathrm{H}(1) \cdots \mathrm{N}(1)$ & $0.86(2)$ & $1.74(2)$ & $2.550(2)$ & $155(2)$ \\
$\mathrm{O}(2)-\mathrm{H}(2) \cdots \mathrm{N}(2)$ & $0.93(2)$ & $1.75(3)$ & $2.613(3)$ & $152(2)$ \\
\hline
\end{tabular}




\section{UV/Vis spectra of HOAr- $\mathrm{NH}_{2}$ and ${ }^{-} \mathrm{OAr}-\mathrm{NH}_{2}$.}

Spectra were taken in acetonitrile. The spectrum of the phenoxide anion ${ }^{-} \mathrm{OAr}-\mathrm{NH}_{2}$ was taken in the presence of excess di(tetra- $n$-butylammonium) succinate $\left(\mathrm{pK}_{\mathrm{a} 2}[\right.$ succinic acid $]=29.0$ in $\mathrm{MeCN})^{8}$ The UV/Vis spectrum of a saturated MeCN solution of $\mathrm{HOAr}-\mathrm{NH}_{2}$ was taken on a CARY 500 spectrometer in a $10.00 \mathrm{~cm}$ quartz cell.

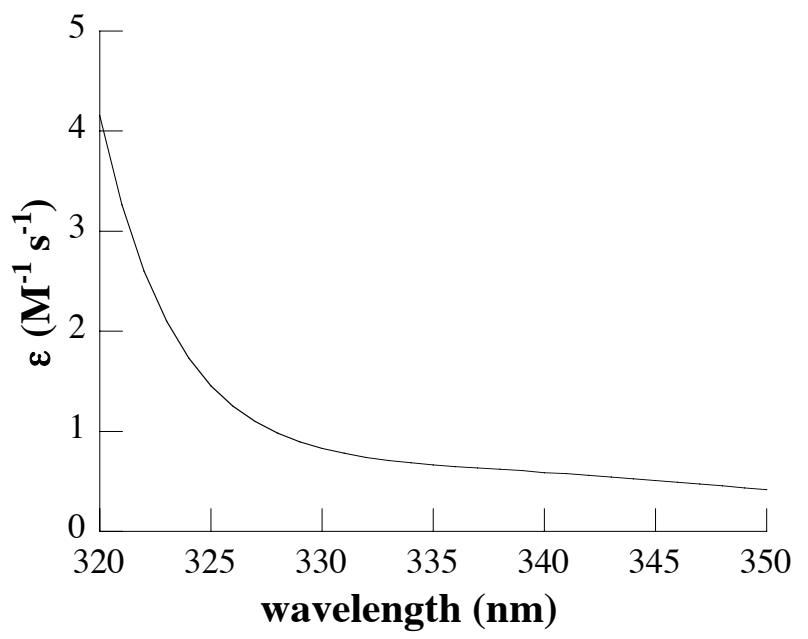

Figure S4. Long-pathlength UV/Vis spectrum of HOAr-NH $\mathbf{N H}_{2}$.

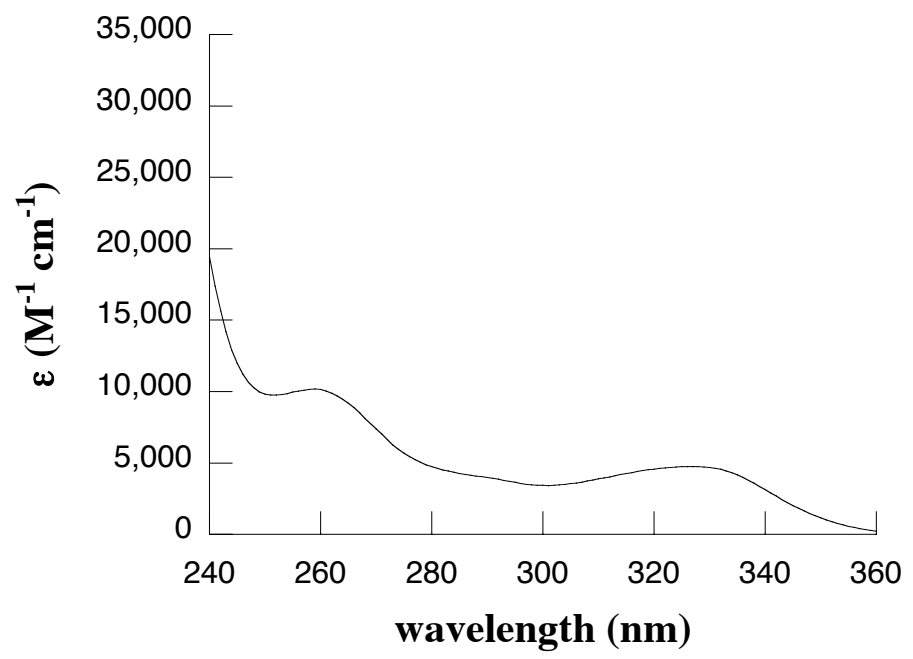

Figure S5. UV/Vis spectrum of ${ }^{-} \mathrm{OAr}-\mathrm{NH}_{2}$.

\section{Kinetics Experiments}

All kinetics experiments were performed on an OLIS RSM-1000 stopped flow apparatus, and analyzed with SpecFit ${ }^{\mathrm{TM}}$ global analysis software. In general, one of three methods were used, depending on the thermodynamics and rate of reaction. Kinetics for the iron complexes were obtained at $0.1 \mathrm{M}^{n} \mathrm{Bu}_{4} \mathrm{NPF}_{6}$ as the potentials for these compounds vary with ionic strength

(8) Izutsu, K. Acid-Base Dissociation Constants in Dipolar Aprotic Solvents Blackwell: Boston, 1990; pp. 17-35. 
due to ion pairing. ${ }^{9}$ The change in potential when ionic strength is varied for the aminium salts was found to be minimal.

For $\left[\mathrm{N}\left(p-\mathrm{C}_{6} \mathrm{H}_{4} \mathrm{OMe}\right)_{2}\left(p-\mathrm{C}_{6} \mathrm{H}_{4} \mathrm{Br}\right)\right]^{++}$and $\left[\mathrm{N}\left(p-\mathrm{C}_{6} \mathrm{H}_{4} \mathrm{OMe}\right)_{3}\right]^{++}$where $K<1$, solutions of 10 100 equiv HOAr-NH $\left.\mathrm{N}_{2}\right)$ were added to $4.6 \times 10^{-5} \mathrm{M}\left[\mathrm{N}\left(p-\mathrm{C}_{6} \mathrm{H}_{4} \mathrm{OMe}\right)_{3}\right]^{++}$or $4.3 \times 10^{-5} \mathrm{M}[\mathrm{N}(p-$ $\left.\left.\mathrm{C}_{6} \mathrm{H}_{4} \mathrm{OMe}\right)_{2}\left(p-\mathrm{C}_{6} \mathrm{H}_{4} \mathrm{Br}\right)\right]^{*+}$. The reactions were fit to two opposing second-order reactions with the oxidant considered to be colored. The derived second-order rate constants do not depend on the amount of aminophenol used, as expected (Figures S6, S7).

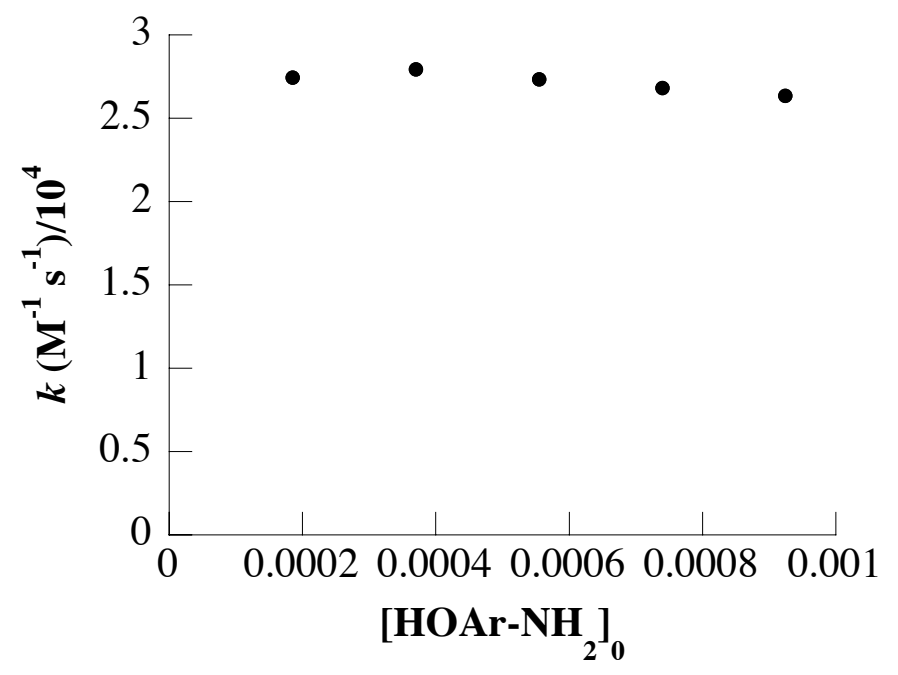

Figure S6. Plot of the second-order forward rate constant $(k)$ vs. [HOAr- $\mathrm{NH}_{2}$ ] for $[\mathrm{N}(p-$ $\left.\left.\mathrm{C}_{6} \mathrm{H}_{4} \mathrm{OMe}\right)_{2}\left(p-\mathrm{C}_{6} \mathrm{H}_{4} \mathrm{OBr}\right)\right]^{++}$

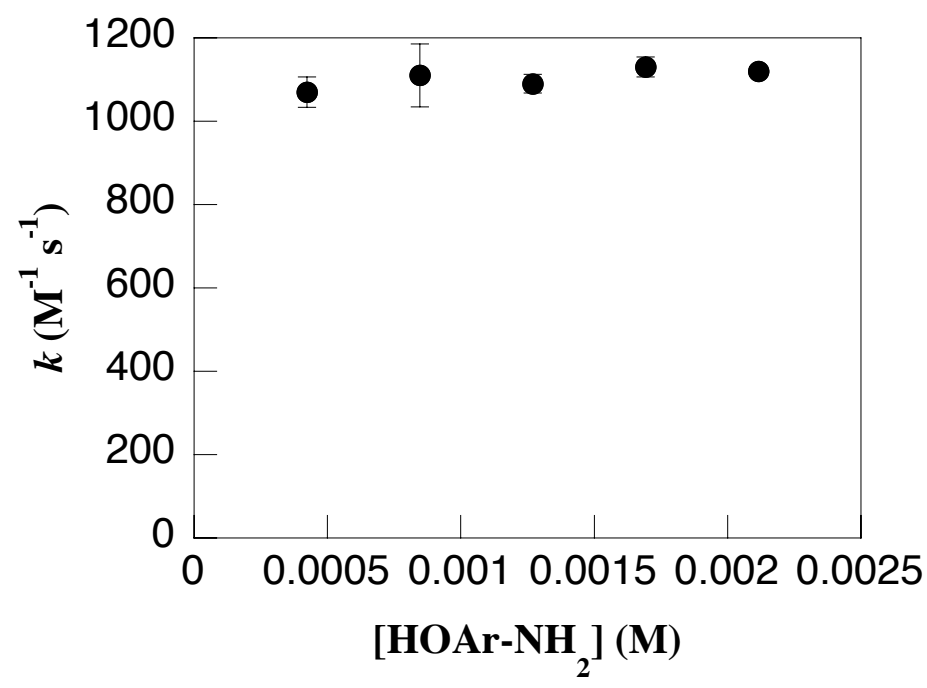

Figure S7. Plot of the second-order forward rate constant $(k)$ vs. [HOAr- $\left.\mathbf{N H}_{2}\right]$ for $[\mathrm{N}(p-$ $\left.\left.\mathrm{C}_{6} \mathrm{H}_{4} \mathrm{OMe}\right)_{3}\right]^{++}$

(9) (a) Noel, M.; Vasu, K. I. Cyclic Voltammetry and the Frontiers of Electrochemistry; Aspect: London, 1990; pp. 141-143 (b) Braga, T. G.; Wahl, A. C. J. Phys. Chem. 1985, 89, 5822-5828. (c) Chan, M.S.; Wahl, A. C. J. Phys. Chem. 1978, 82, 2542-2549. 
For $\left[\mathrm{N}(\mathrm{tol})_{3}\right]^{0^{++}}$and $\mathrm{Fe}\left(5,5^{\prime}-\mathrm{Me}_{2} \text { bpy }\right)_{3}{ }^{3+}$, solutions of $10-50$ eq HOAr- $\mathbf{N H}_{2}$ were added to $1.8 \times$ $10^{-5} \mathrm{M}$ and $1.4 \times 10^{-5} \mathrm{M}$ oxidant, respectively. The reactions were fit to a first-order expression to obtain $k_{\mathrm{obs}}$ at each concentration. The slope of $k_{\mathrm{obs}} \mathrm{v}$. [HOAr-NH $\mathbf{N H}_{2}$ ] is reported as the secondorder rate constant.

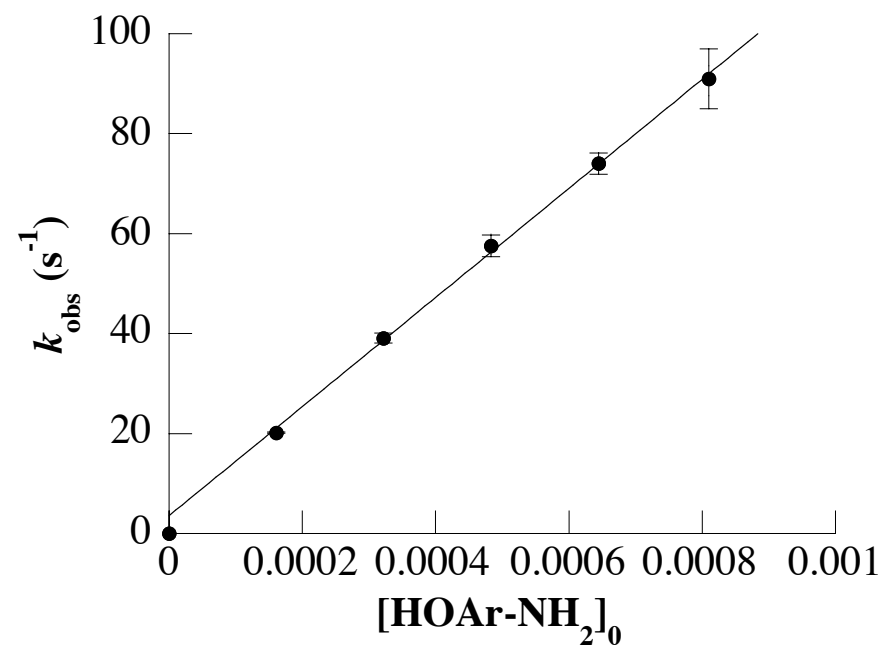

Figure S8. Plot of $k_{\mathrm{obs}}$ vs. [HOAr-NH$]_{0}$ for $\left[\mathrm{N}(\mathrm{tol})_{3}\right]^{\circ+}$

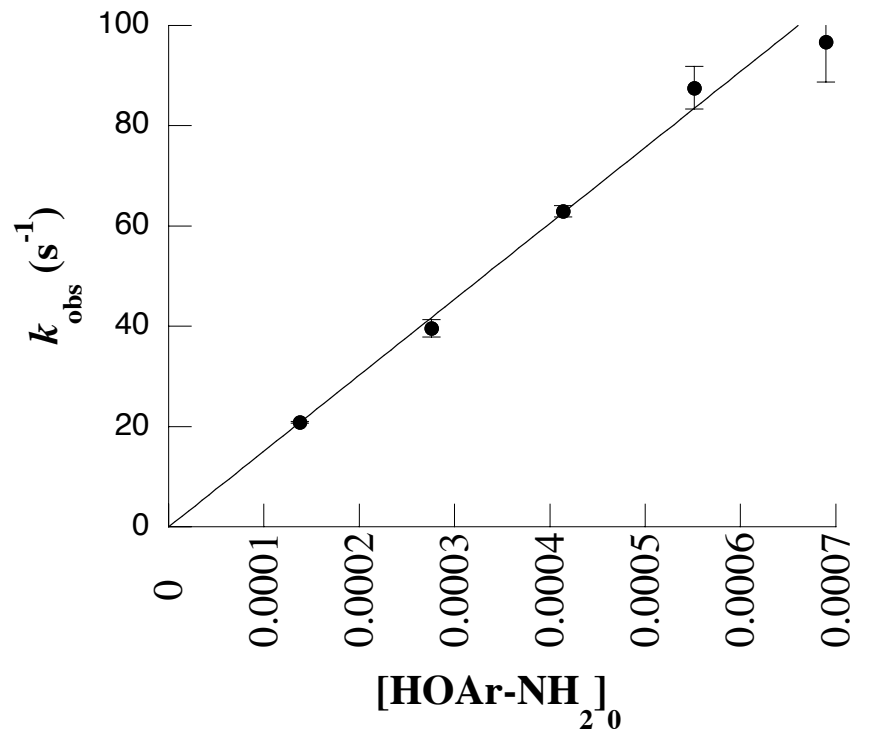

Figure S9. Plot of $k_{\mathrm{obs}}$ vs. [HOAr-NH $]_{0}$ for $\left[\mathrm{Fe}\left(5,5-\mathrm{Me}_{2} \mathrm{bpy}\right)_{3}\right]^{3+}$

The remaining oxidants $\left(\left[\mathrm{N}\left(p-\mathrm{C}_{6} \mathrm{H}_{4} \mathrm{OMe}\right)\left(p-\mathrm{C}_{6} \mathrm{H}_{4} \mathrm{Br}\right)_{2}\right]^{*+},\left[\mathrm{N}\left(p-\mathrm{C}_{6} \mathrm{H}_{4} \mathrm{Br}\right)_{3}\right]^{*+}\right.$, and $\left.\left[\mathrm{Fe}(\mathrm{bpy})_{3}\right]^{3+}\right)$ required second-order conditions because of the speed of the reactions. In each case, $1.05-5$ eq of HOAr- $\mathbf{N H}_{2}$ was added to a solution of the corresponding oxidant in the stopped flow $\left(3.1 \times 10^{-5} \mathrm{M}\right.$ for $\left[\mathrm{N}\left(p-\mathrm{C}_{6} \mathrm{H}_{4} \mathrm{OMe}\right)\left(p-\mathrm{C}_{6} \mathrm{H}_{4} \mathrm{Br}\right)_{2}\right]^{\cdot+}$ and $1.4 \times 10^{-5} \mathrm{M}$ for $\left.\left[\mathrm{Fe}(\mathrm{bpy})_{3}\right]^{3+}\right)$. The reactions were fit to a second-order expression $\mathrm{A}+\mathrm{B} \rightarrow \mathrm{C}$, where $\mathrm{A}$ and $\mathrm{C}$ are colored. Second-order rate constants derived from runs at different phenol concentrations show deviations 
at low [HOAr- $\mathbf{N H}_{2}$ ] (Figure S10) so the lowest points were not used in calculating $k$.

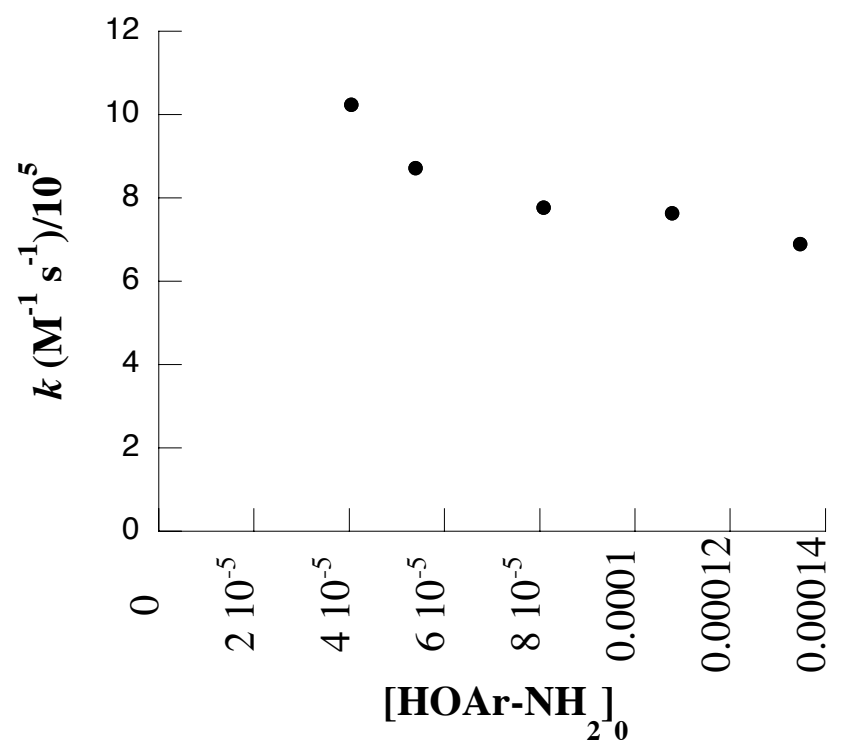

Figure S10. Plot of $k$ vs. [HOAr- $\left.\mathbf{N H}_{2}\right]$ for $\left[\mathrm{N}\left(p-\mathrm{C}_{6} \mathrm{H}_{4} \mathrm{OMe}\right)_{2}\left(p-\mathrm{C}_{6} \mathrm{H}_{4} \mathrm{Br}\right)\right]^{++}$

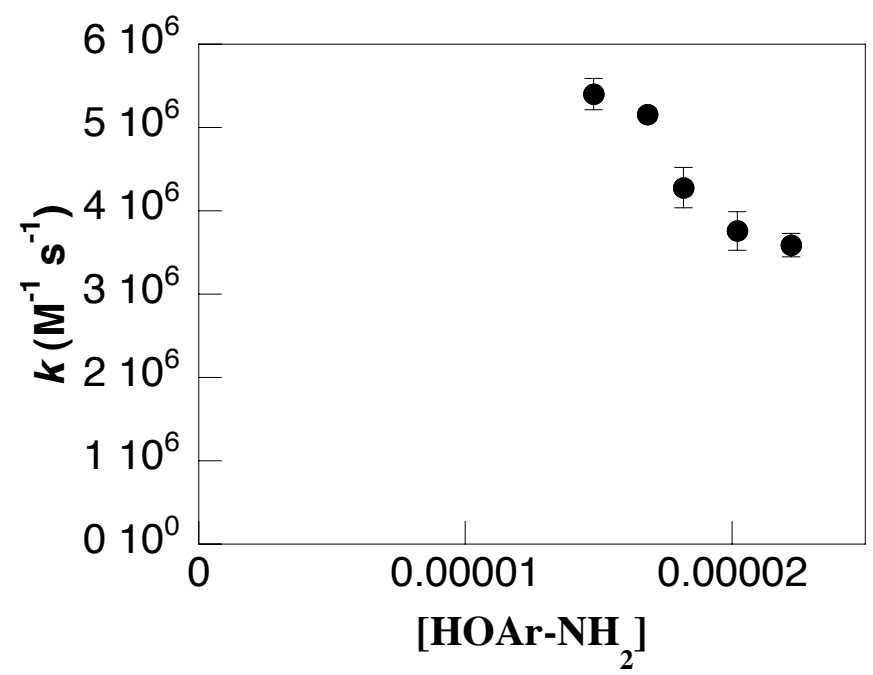

Figure S11. Plot of $k$ vs. [HOAr-NH $\mathbf{N H}_{2}$ for $\left[\mathrm{Fe}(\mathrm{bpy})_{3}\right]^{3+}$

Analysis of the $\mathrm{N}\left(p-\mathrm{BrC}_{6} \mathrm{H}_{4}\right)_{3}{ }^{\cdot+}$ kinetics was performed on a single wavelength as the reaction is very fast and the limited data obtained could not be analyzed by SpecFit. Due to the large rate constant, only one concentration $\left(3.0 \times 10^{-5} \mathrm{M} \mathrm{N}\left(p-\mathrm{BrC}_{6} \mathrm{H}_{4}\right)_{3}{ }^{\cdot+}\right.$ and $3.8 \times 10^{-5} \mathrm{M}$ HOAr- $\mathbf{N H}_{2}$ ) was used. A plot of the absorbance at $700.7 \mathrm{~nm}$ vs. time was fit using the equation below in Microsoft Excel ${ }^{\circledR}{ }^{1}$ The initial absorbance had to be set from stopped flow runs with acetonitrile solution instead of $\mathbf{H O A r}-\mathbf{N H}_{2}$ solution as significant reaction occurred in the mixing period in reactions with $\mathbf{H O A r}-\mathbf{N H}_{2}$ (Figure S12). 


$$
k t=\frac{1}{\left[\mathrm{HOAr}-\mathrm{NH}_{2}\right]_{0}-\left[\mathrm{NAr}_{3}{ }^{*+}\right]_{0}} \ln \frac{\left(\left[\mathrm{HOAr}-\mathrm{NH}_{2}\right]_{0}-\left[\mathrm{NAr}_{3}{ }^{+}\right]_{0}\left(\mathrm{abs} / \mathrm{abs}_{0}\right)\right) /\left[\mathrm{HOAr}-\mathrm{NH}_{2}\right]_{0}}{\left(\mathrm{abs}_{0} / \mathrm{abs}_{0}\right)}
$$

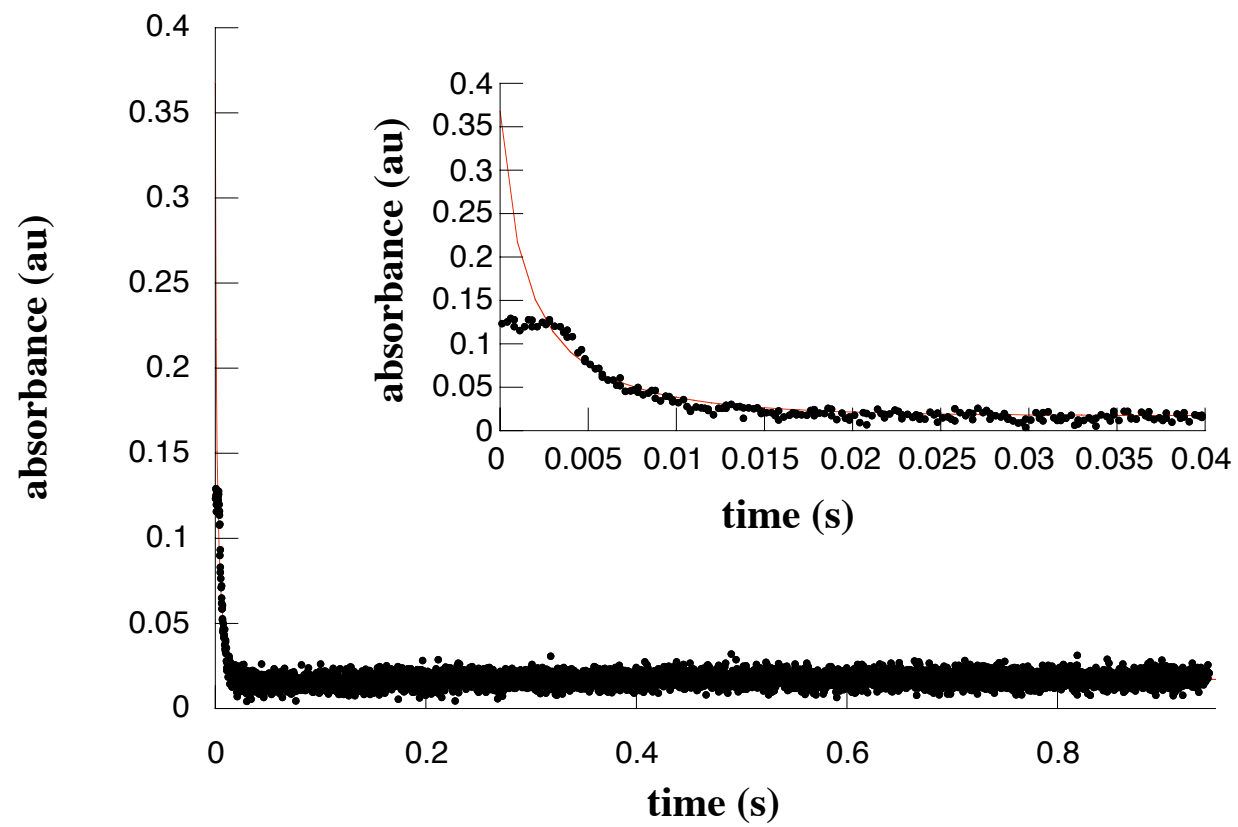

Figure S12. Plot of absorbance vs. time for $\left[\mathrm{N}\left(p-\mathrm{BrC}_{6} \mathrm{H}_{4}\right)_{3}\right]^{0+}$. The lines are the fitted data.

\section{Kinetic Isotope Effect}

The solution of $\mathrm{HOAr}-\mathrm{NH}_{2}$ was prepared at $1 \% \mathrm{v} / \mathrm{v} \mathrm{CH}_{3} \mathrm{OD}$, and the kinetics performed otherwise as above. A rate constant of $(4.7 \pm 0.5) \times 10^{4} \mathrm{M}^{-1} \mathrm{~s}^{-1}$ was measured. It was estimated by ${ }^{1} \mathrm{H}$ NMR that the $\mathrm{CH}_{3} \mathrm{OD}$ was $6.9 \% \mathrm{CH}_{3} \mathrm{OH}$ and $95.1 \% \mathrm{CH}_{3} \mathrm{OD}$. Kinetics performed with $1 \%$ $\mathrm{v} / \mathrm{v} \mathrm{CH}_{3} \mathrm{OH}$ yielded an indentical rate constant as above. The isotope effect was corrected by the formula $\left(k_{\mathrm{H}} / k_{\mathrm{D}}\right)_{\text {corr }}=k_{\mathrm{H}, \mathrm{obs}} f_{\mathrm{D}} /\left(k_{\mathrm{D}, \text { obs }}-k_{\mathrm{H}, \text { obs }}\left(1-f_{\mathrm{D}}\right)\right)$, where $f_{\mathrm{D}}$ is the fraction of deuterium in the $\mathrm{HOAr}-\mathrm{NH}_{2}$.

\section{Plot of $\Delta \Delta G^{\ddagger}$ vs. $\Delta \Delta G^{\circ}\left(\mathrm{kcal} \mathrm{mol}^{-1}\right)$}

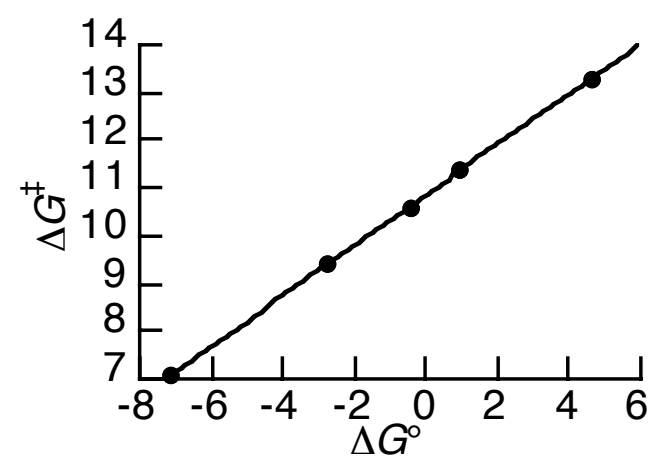




\section{Equilibration Experiments}

$\boldsymbol{K}_{\mathrm{N}(\mathrm{ArOMe}) 2(\mathrm{ArBr})}$ and $\boldsymbol{K}_{\mathrm{N}(\mathrm{ArOMe}) 3}$. For these compounds, the equilibrium constant was derived from the kinetics (see above) as a ratio of the forward and reverse rate constants $\left(K=k_{\mathrm{f}} / k_{\mathrm{b}}\right)$.

$\boldsymbol{K}_{\mathrm{Ntol3}}$. The equilibrium constant for reaction with $\mathrm{Ntol}_{3}{ }^{-+}$was determined in two different ways.

Method 1. The first method involved varying the concentration of $\mathrm{Ntol}_{3}\left(0 \mathrm{M}\right.$ to $\left.1.8 \times 10^{-4} \mathrm{M}\right)$ in an equilibrated solution of $\mathrm{Ntol}_{3}{ }^{-+}$(initial concentration of $5.7 \times 10^{-5} \mathrm{M}$ ) and $\mathbf{H O A r N H}$ (initial concentration of $5.9 \times 10^{-5} \mathrm{M}$ ) and determination of the final absorbance at $669 \mathrm{~nm} \mathrm{Ntol}{ }^{\circ+}$. The absorbance of a solution of $\mathrm{Ntol}_{3}{ }^{++}\left(5.7 \times 10^{-5} \mathrm{M}\right)$ was used to determine the final concentrations of the individual equilibrated solutions. An expression relating the absorbance of $\mathrm{Ntol}_{3}{ }^{\circ+}$ to [ $\left.\mathrm{Ntol}_{3}\right]$ in terms of $K_{\mathrm{Ntol} 3}$ was derived, and a nonlinear least squares fit was applied using Excel ${ }^{\circledR}$ (Figure $\mathrm{S} 13) .{ }^{1} K_{\mathrm{Ntol} 3}$ by this method was 2.4 .

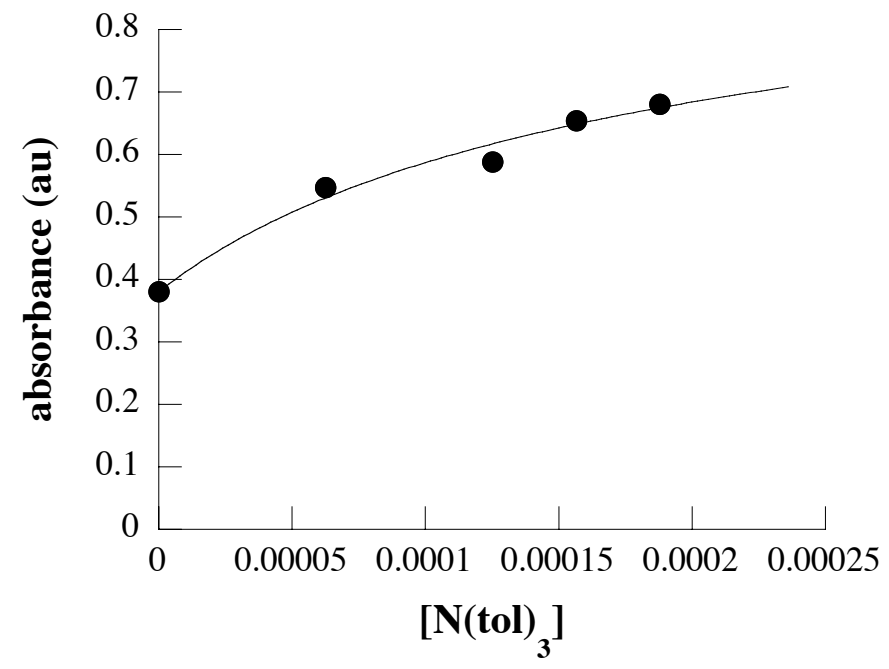

Figure S13. Graph of absorbance vs. $\left[\mathrm{N}(\mathrm{tol})_{3}\right]$ for the first method of determination of $K_{\mathrm{Ntol} 3}$. The line represents $K=2.4$.

Method 2. The second involved addition of triflic acid to a solution with a large excess of $\mathrm{Ntol}_{3}$ and HOAr- $\mathbf{N H}_{2}$ to $\mathrm{Ntol}_{3}{ }^{-+}$. This allowed for the determination of whether proton equilibrium between the radical's amino group and the phenol's amino group (eq 2) influenced the equilibrium. Hence, two equilibria were taken into account:

$$
\begin{aligned}
& \mathrm{Ntol}_{3}{ }^{\circ+}+\mathbf{H O A r}-\mathrm{NH}_{2} \quad \rightleftarrows \quad \mathrm{Ntol}_{3}+{ }^{\cdot} \mathrm{OArNH}_{3}^{+} \quad K_{\mathrm{Ntol} 3} \\
& \mathrm{HOAr}-\mathrm{NH}_{2}+\cdot \mathrm{OAr}-\mathrm{NH}_{3}^{+} \quad \rightleftarrows \quad \mathrm{OArNH}_{2}^{+}+\mathrm{HOArNH}_{3}^{+} \quad K_{\sim \mathrm{H}+}
\end{aligned}
$$

The triflic acid is also added in large excess relative to $\mathrm{Ntol}_{3}{ }^{++}$, and hence the [HOAr-NH $\mathbf{N H}_{2}$, $\left[\mathrm{HOAr}-\mathrm{NH}_{3}{ }^{+}\right]$, and $\left[\mathrm{Ntol}_{3}\right]$ may be considered constant in a mathematical derivation (as $\left[\text { HOAr- }-\mathrm{NH}_{2}\right]_{\mathrm{c}},\left[\mathrm{HOAr}-\mathrm{NH}_{3}{ }^{+}\right]_{\mathrm{c}}$, and $\left.\left[\mathrm{Ntol}_{3}\right]_{\mathrm{c}}\right)$.

From the equilibrium expressions (1) and (2), it is known:

$$
K_{\mathrm{Ntol}_{3}}=\frac{\left[\mathrm{HOAr}-\mathrm{NH}_{2}\right]_{\mathrm{c}}\left[\mathrm{Ntol}_{3}{ }^{{ }^{+}}\right]_{\mathrm{f}}}{\left[{ }^{\circ} \mathrm{OAr}-\mathrm{NH}_{3}{ }^{+}\right]\left[\mathrm{Ntol}_{3}\right]_{\mathrm{c}}}
$$




$$
K_{\sim \mathrm{H}^{+}}=\frac{\left[\mathrm{HOAr}-\mathrm{NH}_{2}\right]_{\mathrm{c}}\left[{ }^{\circ} \mathrm{OAr}-\mathrm{NH}_{3}{ }^{+}\right]}{\left[{ }^{\circ} \mathrm{OAr}-\mathrm{NH}_{2}\right]\left[\mathrm{HOAr}-\mathrm{NH}_{3}{ }^{+}\right]_{\mathrm{c}}}
$$

Also from the equilibrium expressions, an equation for mass balance may be obtained:

$$
\left[{ }^{\circ} \mathrm{OAr}-\mathrm{NH}_{2}\right]=\left(\left[\mathrm{Ntol}_{3}{ }^{+}\right]_{\mathrm{i}}-\left[\mathrm{Ntol}_{3}{ }^{+{ }^{+}}\right]_{\mathrm{f}}\right)-\left[{ }^{\circ} \mathrm{OAr}-\mathrm{NH}_{3}{ }^{+}\right]
$$

In these expression $\left[\mathrm{Ntol}_{3}{ }^{\circ+}\right]_{\mathrm{i}}$ and $\left[\mathrm{Ntol}_{3}{ }^{\circ+}\right]_{\mathrm{f}}$ are the initial and final concentrations of $\mathrm{Ntol}_{3}{ }^{\circ+}$, respectively.

Substituting (5) into (4) yields:

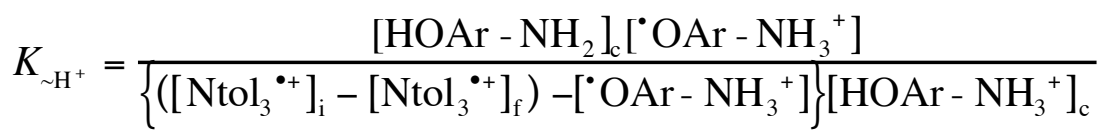

Solving both (6) and (3) for [ $\left[\mathrm{OArNH}_{3}{ }^{+}\right]$yields (7) and (8).

$$
\begin{aligned}
& {\left[{ }^{\bullet} \mathrm{OAr}-\mathrm{NH}_{3}^{+}\right]=\frac{K_{\mathrm{H}}\left(\left[\mathrm{Ntol}_{3}{ }^{+{ }^{+}}\right]_{\mathrm{i}}-\left[\mathrm{Ntol}_{3}{ }^{+}\right]_{\mathrm{f}}\right)\left[\mathrm{HOAr}-\mathrm{NH}_{3}^{+}\right]}{K_{\mathrm{H}}\left[\mathrm{HOAr}-\mathrm{NH}_{3}{ }^{+}\right]_{\mathrm{c}}-\left[\mathrm{HOAr}-\mathrm{NH}_{2}\right]_{\mathrm{c}}}} \\
& {\left[{ }^{\cdot} \mathrm{OAr}-\mathrm{NH}_{3}^{+}\right]=\frac{\left[\mathrm{HOAr}-\mathrm{NH}_{2}\right]_{\mathrm{c}}\left[\mathrm{Ntol}_{3}{ }^{{ }^{+}}\right]_{\mathrm{f}}}{K_{\mathrm{Ntol}_{3}}\left[\mathrm{Ntol}_{3}\right]_{\mathrm{c}}}}
\end{aligned}
$$

Equating (7) and (8) and rearranging gives an expression in terms of the essentially constant concentrations and the change in $\left[\mathrm{Ntol}_{3}{ }^{\circ}\right]$ :

$$
\frac{\left[\mathrm{Ntol}_{3}{ }^{+}\right]_{\mathrm{i}}}{\left[\mathrm{Ntol}_{3}{ }^{+}\right]_{\mathrm{f}}}=1+\frac{K_{\mathrm{Ntol}_{3}}\left[\mathrm{HOAr}-\mathrm{NH}_{2}\right]_{\mathrm{c}}\left(K_{\sim \mathrm{H}^{+}}\left[\mathrm{HOAr}-\mathrm{NH}_{2}\right]_{\mathrm{c}}+\left[\mathrm{HOAr}-\mathrm{NH}_{3}^{+}\right]_{\mathrm{c}}\right)}{\left[\mathrm{Ntol}_{3}\right]_{\mathrm{C}}\left[\mathrm{HOAr}-\mathrm{NH}_{3}^{+}\right]_{\mathrm{c}}}
$$

Two limiting cases of this expression are possible. When $K_{\sim \mathrm{H}^{+}}\left[\mathrm{HOAr}-\mathrm{NH}_{2}\right]>>[\mathrm{HOAr}-$ $\mathrm{NH}_{3}^{+}$, the expression simplifies to eq 10 :

$$
\frac{\left[\mathrm{Ntol}_{3}{ }^{+}\right]_{\mathrm{i}}}{\left[\mathrm{Ntol}_{3}{ }^{+}\right]_{\mathrm{f}}}=1+\frac{K_{\mathrm{Ntol}_{3}} K_{\sim \mathrm{H}^{+}}\left[\mathrm{HOAr}-\mathrm{NH}_{2}\right]_{\mathrm{C}}^{2}}{\left[\mathrm{Ntol}_{3}\right]_{\mathrm{c}}\left[\mathrm{HOAr}-\mathrm{NH}_{3}^{+}\right]_{\mathrm{c}}}
$$

When $\left.K_{\sim \mathrm{H}^{+}}\left[\mathrm{HOArNH}_{2}\right]<<\mathrm{HOArNH}_{3}^{+}\right]$,

$$
\frac{\left[\mathrm{Ntol}_{3}{ }^{++}\right]_{\mathrm{i}}}{\left[\mathrm{Ntol}_{3}{ }^{++}\right]_{\mathrm{f}}}=1+\frac{K_{\mathrm{Ntol}_{3}}\left[\mathrm{HOAr}-\mathrm{NH}_{2}\right]_{\mathrm{c}}}{\left[\mathrm{Ntol}_{3}\right]_{\mathrm{c}}}
$$


Solutions were prepared with constant initial concentrations of $\mathrm{Ntol}_{3}(0.00319 \mathrm{M})$ and $\mathrm{Ntol}_{3} \mathrm{PF}_{6}$ $\left(3.15 \times 10^{-5} \mathrm{M}\right)$, and the concentrations of HOAr- $\mathbf{N H}_{2}$ were varied by varying the concentrations of HOTf (see Table S3). The absorbance of each solution at $669 \mathrm{~nm}$ was taken, as well as a solution that contained only $3.15 \times 10^{-5} \mathrm{M} \mathrm{Ntol}_{3} \mathrm{PF}_{6}$. The expressions were fit to equations 9, 10, and 11 above as $\operatorname{abs}_{\left\{\mathrm{Nol}_{3}{ }^{\circ+}\right\}_{f}} / \mathrm{abs}_{\left\{\mathrm{Nol}_{3}{ }^{+}\right\}_{\mathrm{i}}}=\left[\mathrm{Ntol}_{3}{ }^{\circ+}\right]_{\mathrm{f}} /\left[\mathrm{Ntol}_{3}{ }^{\circ+}\right]_{\mathrm{i}}($ Figure S14).

Expression 10, where $K_{\sim \mathrm{H}^{+}}\left[\mathrm{HOAr}-\mathrm{NH}_{2}\right]>>$ [HOAr- $\left.\mathrm{NH}_{3}{ }^{+}\right]$, clearly does not fit data, the fits from equations 9 and 11 indicate that the proton equilibrium (eq 2) must not be important. Expression 9 yielded $K_{\mathrm{Ntol} 3}=1.3$ and expression 10 yielded $K_{\mathrm{Ntol} 3}=1.5$. Note the scatter in the data results primarily from the instability of $\mathrm{HOAr}-\mathrm{NH}_{3}{ }^{+}$over long periods of time.

Table S3. Absorbance vs. $\left[\mathrm{HOAr}-\mathrm{NH}_{2}\right]$ and $\left[\mathrm{HOAr}-\mathrm{NH}_{3}{ }^{+}\right]$for the second method of determining $K_{\mathrm{Ntol} 3}$.

\begin{tabular}{ccc}
\hline$\left[\mathbf{H O A r}-\mathbf{N H}_{2}\right]$ & {$\left[\mathbf{H O A r}-\mathbf{N H}_{3}{ }^{+}\right]$} & absorbance $(\mathrm{au})$ \\
\hline 0.00297 & 0.000560 & 0.18357 \\
0.00241 & 0.00112 & 0.17688 \\
0.00185 & 0.00168 & 0.20514 \\
0.00129 & 0.00224 & 0.24925 \\
0.00269 & 0.000840 & 0.19075 \\
0.00101 & 0.00252 & 0.25328 \\
0 & 0 & 0.366164 \\
\hline
\end{tabular}

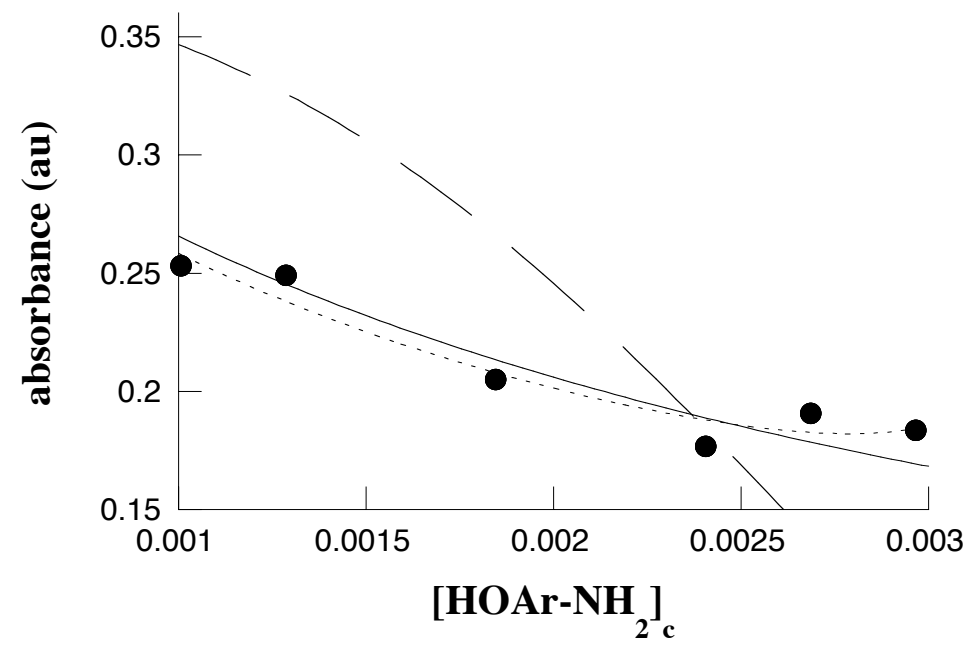

Figure S14. Second determination of $K_{\mathrm{Ntol3}}$. The solid line represents the case where $K_{\sim \mathrm{H}^{+}}\left[\mathrm{HOAr}-\mathrm{NH}_{2}\right]<<$ HOAr- $\left.\mathrm{NH}_{3}{ }^{+}\right]$(equation 11); the dashed line represents the case where $K_{\sim \mathrm{H}^{+}}\left[\mathrm{HOAr}-\mathrm{NH}_{2}\right] \gg$ [HOAr- $\left.\mathrm{NH}_{3}{ }^{+}\right]$(equation 10); and the dotted line represents fitting to the full expression (equation 9).

Estimation of $E_{\mathrm{HOAr}-\mathrm{NH} 2}$ from $K$ and

$\mathbf{E}_{1 / 2}$ values. A plot of $\mathrm{E}$ vs. $\log K$ (Figure $\left.\mathrm{S} 15\right)$

has intercept (at $\log K=0$ ) of $0.36 \mathrm{~V}$. 


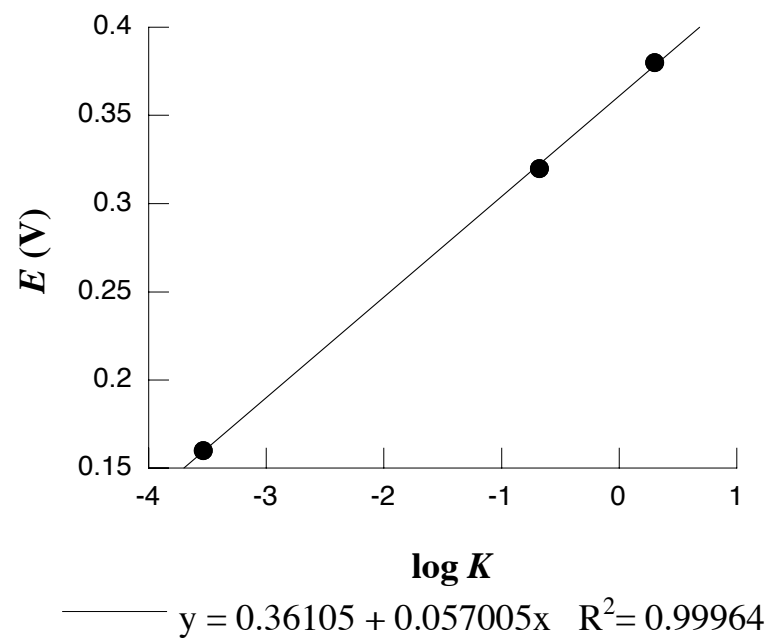

Figure S15. $E$ v. $\log K$, to give $E_{\mathrm{HOAr}_{-} \mathrm{NH}_{2}}{ }^{\circ}$

\section{Electrochemistry}

Cyclic voltammograms were taken on an E2 Epsilon electrochemical analyzer (Bioanalytical Systems) in $0.1 \mathrm{M}^{n} \mathrm{Bu}_{4} \mathrm{NPF}_{6}$ in acetonitrile (unless otherwise noted) with about 5 $\mathrm{mM}$ substrate. The electrodes were as follows: working, platinum disc (oxidants or their reduced forms) or glassy carbon (phenol); auxiliary, platinum wire; and reference, $\operatorname{Ag} / \operatorname{AgNO}_{3}(0.01 \mathrm{M})$ in electrolyte solution. Ferrocene was added such that $\mathrm{Cp}_{2} \mathrm{Fe}^{+/ 0}$ was used as an internal standard.

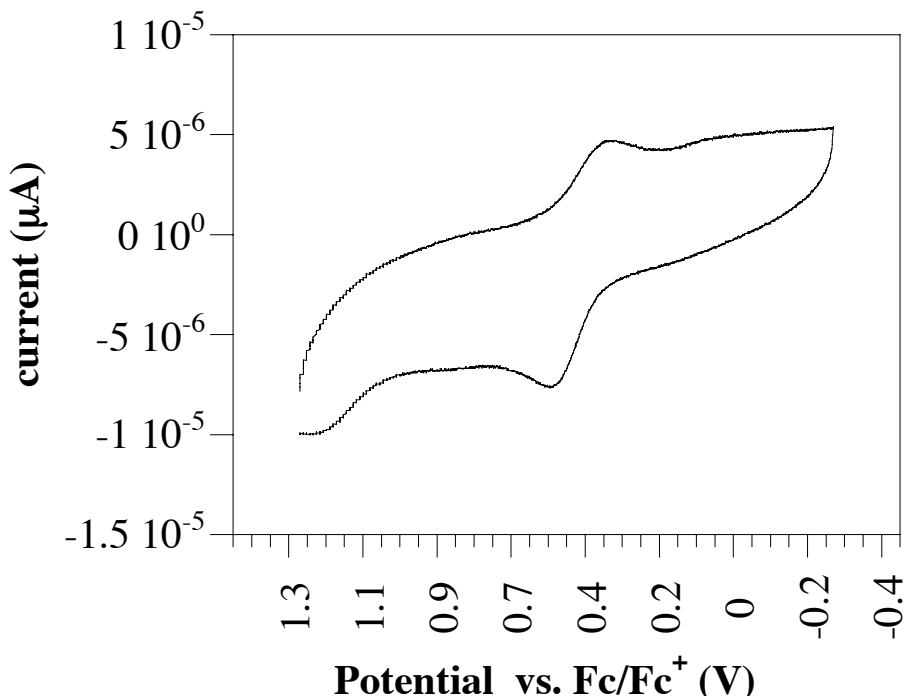

Figure S16. Cyclic voltammogram for $\mathrm{HOAr}-\mathrm{NH}_{2}$. 


\section{EPR Spectrum}

The EPR spectrum was recorded on a Bruker EPX CW-EPR spectrometer operating at Xband frequency at room temperature (Figure $\mathrm{S} 17)$. A solution that was originally $5 \mathrm{mM}$ HOAr- $\mathrm{NH}_{2}$ and $1 \mathrm{mM} \mathrm{N}\left(p-\mathrm{C}_{6} \mathrm{H}_{4} \mathrm{Br}\right)_{3}{ }^{\cdot+}$ in methylene chloride was used.

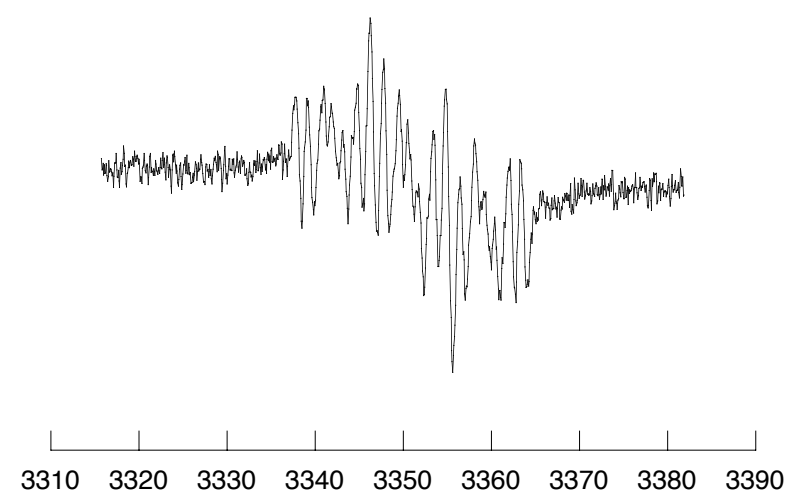

Figure S17. EPR spectrum of ${ }^{\circ} \mathrm{OAr}-\mathrm{NH}_{3}^{+}$.

\section{Estimation of $\Delta G_{\mathrm{ET} 1}$ for the ET-PT mechanism}

The redox potential for 2,4,6-tri- $t$-butylphenol ( $\left.{ }^{\mathrm{t}} \mathrm{Bu}_{3} \mathrm{ArOH}\right)$ in $\mathrm{MeCN}$ is to be $1.85 \mathrm{~V}$ vs. $\mathrm{Ag} / \mathrm{AgI}$ in acetonitrile. ${ }^{10}$ This paper gives $E_{\mathrm{Ag} / \mathrm{Ag}^{+}}=E_{\mathrm{SCE}}+0.365 \mathrm{~V}$. Using $E_{\mathrm{Fc} / \mathrm{Fc}}+=E_{\mathrm{SCE}}-0.40 \mathrm{~V},{ }^{11}$ the potential for ${ }^{t} \mathrm{Bu}_{3} \mathrm{ArOH}$ in $\mathrm{MeCN}$ is $1.09 \mathrm{~V}$ vs. $\mathrm{Cp}_{2} \mathrm{Fe}^{+/ 0}$. The potential of $0.38 \mathrm{~V}$ for the $\mathrm{Ntol}_{3}{ }^{++}$, which we have measured vs. $\mathrm{Cp}_{2} \mathrm{Fe}^{+/ 0}$ in the same $\mathrm{MeCN}$ solution, indicates that $\Delta G_{\mathrm{ET}}$ for the ET reaction (12) below is $-0.71 \mathrm{eV}, 16.4 \mathrm{kcal} \mathrm{mol}^{-1}, K_{\mathrm{ET}}=10^{-12}$. We take this to be a good estimate for ET from $\mathrm{HOAr}-\mathrm{NH}_{2}$ to $\mathrm{Ntol}_{3}{ }^{++}$in which the proton remains bound to the phenol, reaction (13).

$$
\begin{aligned}
& { }^{\mathrm{t}} \mathrm{Bu}_{3} \mathrm{ArOH}+\mathrm{Ntol}_{3}{ }^{\cdot+} \rightarrow{ }^{\mathrm{t}} \mathrm{Bu}_{3} \mathrm{ArOH}^{\cdot+}+\mathrm{Ntol}_{3} \\
& \mathrm{HOAr}_{-} \mathrm{NH}_{2}+\mathrm{Ntol}_{3}{ }^{++} \rightarrow{ }^{\circ+} \mathrm{HOAr}_{-} \mathrm{NH}_{2}+\mathrm{Ntol}_{3}
\end{aligned}
$$

(10) Bordwell, F. G.; Cheng, J.-P. J. Am. Chem. Soc. 1991, 113, 1736-1743.

(11) Connelly, N. G.; Geiger, W. E. Chem. Rev. 1996, 96, 877-910. 


\section{$X$. Analysis of a stepwise mechanism involving a successor complex}

A reviewer suggested a stepwise mechanism involving formation of precursor and successor complexes, as summarized in the Scheme below.

$$
\begin{aligned}
& 10^{10} \mathrm{M}^{-1} \mathrm{~s}^{-1} \\
& \mathrm{HOAr}-\mathrm{NH}_{2}+\mathrm{Ntol}_{3}{ }^{+\bullet} \rightleftharpoons\left[\mathrm{HOAr}-\mathrm{NH}_{2} \mid \mathrm{Ntol}_{3}{ }^{+\bullet}\right] \\
& 10^{10} \mathrm{~s}^{-1} \\
& 10^{13} \mathrm{~s}^{-1} \| 2.2 \times 10^{5} \mathrm{~s}^{-1} \quad\left(K_{\mathrm{ET} 1}=2.2 \times 10^{-8}\right) \\
& {\left[{ }^{+} \mathrm{HOAr}-\mathrm{NH}_{2} \mid \mathrm{Ntol}_{3}\right]} \\
& 1.1 \times 10^{5} \mathrm{~s}^{-1} \| 10^{13} \mathrm{~s}^{-1} \\
& {\left[{ }^{\circ} \mathrm{OAr}-\mathrm{NH}_{3}{ }^{+} \mid \mathrm{Ntol}_{3}\right] \stackrel{10^{10} \mathrm{~s}^{-1}}{\underset{10^{10} \mathrm{M}^{-1} \mathrm{~s}^{-1}}{\rightleftharpoons}}{ }^{\circ} \mathrm{OAr}-\mathrm{NH}_{3}{ }^{+}+\mathrm{Ntol}_{3}}
\end{aligned}
$$

To explain the kinetics of the reaction of $\mathrm{HOAr}-\mathrm{NH}_{2}$ with $\mathrm{Ntol}_{3}{ }_{3}^{+\bullet}$, this Scheme must assume:

(i) The equilibrium constant $K_{\mathrm{ET} 1}$ must be no smaller than $2.2 \times 10^{-8}$. As described above, we estimate this equilibrium constant to be $10^{-12}$, so this estimate would have to be in error by $5 \times 10^{-3}$.

(ii) The rate constant for back electron transfer within the successor complex $\left[{ }^{+*} \mathrm{HOAr}-\mathrm{NH}_{2} \mid \mathrm{Ntol}_{3}\right]$ must be the largest possible value, $10^{13} \mathrm{~s}^{-1}$.

(iii) The rate constant for proton transfer within the successor complex $\left[{ }^{+} \mathrm{HOAr}-\mathrm{NH}_{2} \mid \mathrm{Ntol}_{3}\right]$ must be the largest possible value, $10^{13} \mathrm{~s}^{-1}$.

Rate constants of $10^{13} \mathrm{~s}^{-1}$ imply a half life of $70 \mathrm{fs}$. Since there are two processes (electron and proton transfer) that deplete $\left[{ }^{+*} \mathrm{HOAr}-\mathrm{NH}_{2} \mid \mathrm{Ntol}_{3}\right]$ at $10^{13} \mathrm{~s}^{-1}$, the lifetime of this "intermediate" would be $35 \mathrm{fs}$. This is so short that it probably shouldn't be termed an intermediate. $35 \mathrm{fs}$ corresponds to one vibrational period for a $1,000 \mathrm{~cm}^{-1}$ stretching mode, and is less than one vibrational period for all of the bending and breathing vibrational modes in $\mathrm{HOAr}-\mathrm{NH}_{2}$.

Even more stringent limits are set by the reaction of $\mathrm{HOAr}-\mathrm{NH}_{2}$ with $\left[\mathrm{N}\left(p-\mathrm{C}_{6} \mathrm{H}_{4} \mathrm{OMe}\right)_{3}\right]^{++}$. In this case, pure electron transfer is uphill by an additional $0.22 \mathrm{~V}$ (see Table 1) so the equilibrium constant is less favorable by $5 \times 10^{-3}$. The rate constant only slows, however, by a factor of $10^{2}$. Repeating the analysis above, $K_{\mathrm{ETI}}$ would have to be in error by an additional factor of 50 for this to fit this model. And it is difficult for both the $\mathrm{Ntol}_{3}{ }^{+{ }^{+}}$and $\mathrm{N}\left(p-\mathrm{C}_{6} \mathrm{H}_{4} \mathrm{OMe}\right)_{3}{ }^{\circ+}$ reactions to have back reactions at $10^{13} \mathrm{~s}^{-1}$, because both cannot be activationless $\left(\Delta G^{\circ}=-\lambda\right)$. If the $\mathrm{Ntol}_{3}{ }^{\circ+}$ back reaction has $\Delta G^{\circ}=-\lambda$, for instance, the $\mathrm{N}\left(p-\mathrm{C}_{6} \mathrm{H}_{4} \mathrm{OMe}\right)_{3}{ }^{*+}$ back reaction should be in the inverted region. 